\title{
THE INTERNATIONAL CONGRESS OF SOIL SCIENCE
}

By DR. P. S. BURGESS, Ph.D.

Arizona to Be Represented at the First International Soil Science Congress To Be Held on American Soil-Foreign Delegates to Tour the

United States Following the Convention

$\mathbf{D}$ URING this com ing spring there will be held in Washington, D. C., a series of meetings which should be of great interest to all students of soil fertility and the several related sciences. For the first time the International Congress of Soil Science is to meet on American soil. Three or four Congresses have already been held in Europe, but this is the first time it is to cross the Atlantic. Over 200 foreign investigators, many of them of world wide reputation, will be present to deliver addresses and read papers on research problems. The meetings, which will be held in the United States Chamber of Commerce Building, open on June 13 , and close June 22 . The forenoons will be spent in large general sessions for the reading and discussion of invited papers, while during the afternoons the divisions of soil chemistry, soil bacteriology, soil physics, soil fertility, soil mapping, classification and nomenclature, irrigation and soil drainage will hold separate

\section{YEARS IN} ARIZONA

SUPPLYING THE PEOPLE OF ARIZONA

WITH

\section{BUILDING MATERIALS}

That Carry an Ironclad

Guarantee of Quality

\section{J. Knox Corbett}

Lumber \& Hardware Co. North 6th Ave.

Tucson symposia. It is estimated that at least 500 will be in attendance. Addresses by the President of the United States, the Secretary of State and the Secretary of Agriculture are scheduled for the first day while the evenings will be occupied by receptions, dinners, and open meetings.

Our own College of Agriculture will be represented by the writer, who will present a paper entitled, "Soil Com pounds Invloved in Base Exchange Reactions," before the Division of Soil Chemistry.

At the close of the Congress a special Pullman train will be provided to carry the foreign delegates and as many of the American scientists as care to go, on a transcontinental excursion through the South and West to the Pacific coast, north to Portland, Seattle and Vancouver, and back east by the northern route to Washington. On this trip, soil and geological examinations will be made at frequent stops, and general agricultural conditions noted.

It is expected that the complete proceedings of the Congress will be published, including the addresses given before the general sessions and the research papers presented at the several divisional symposia.
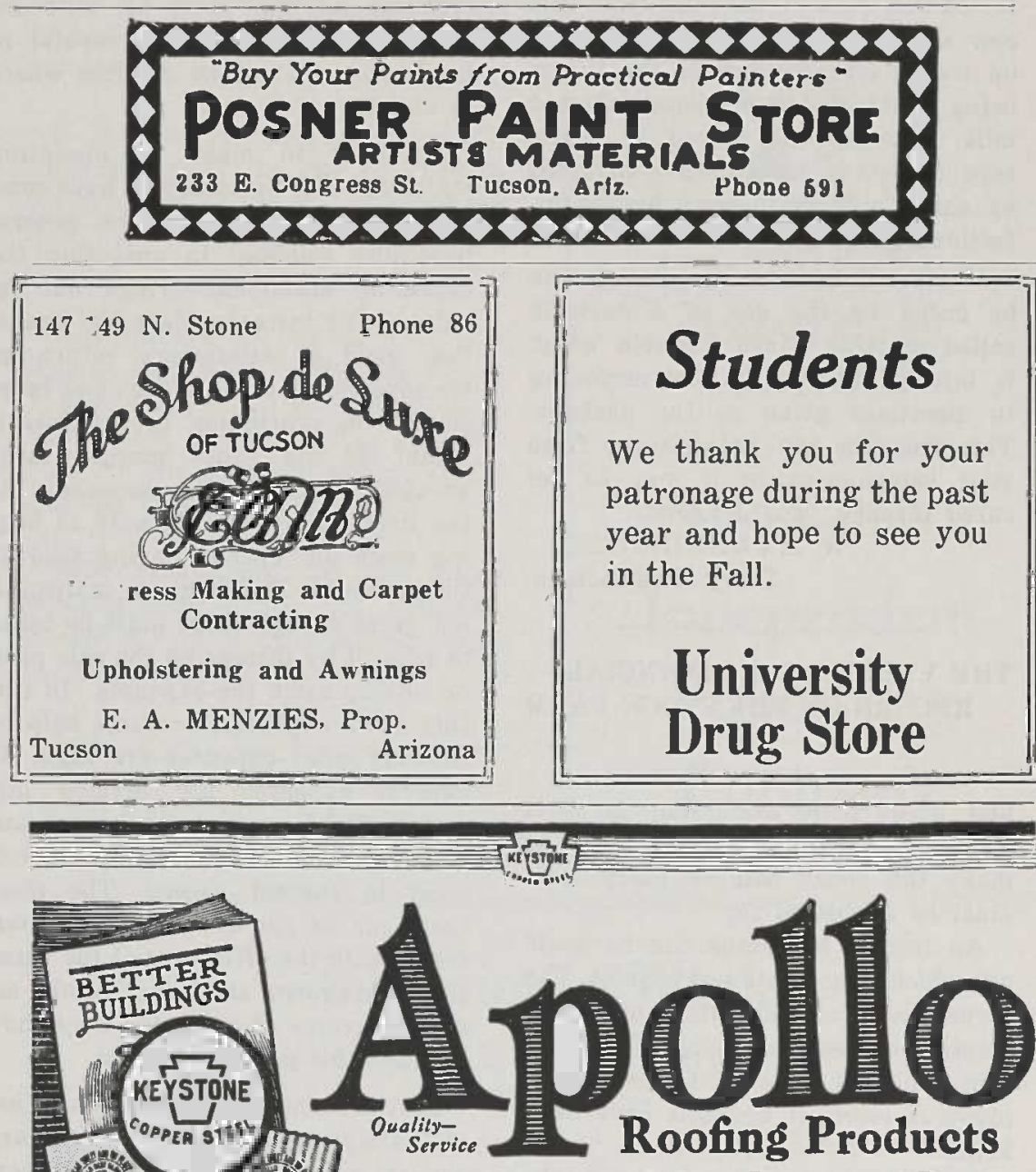

Why build to burn? Use Galvanized Roofing for farm buildings - and Tin Roofs for homes. APOLLO.KETBTONE Galvanized Sheets not only last longest for Roofing and Siding, but are specially adapted for Oulverts, Tanks, Bilos, Spoutine. and all exposed shoet mets work. KEYrroNe Coppor steel Roo6ng Tin Plates also give unequaled service. Sold by lesding metal merchanth. AMERICAN SHEET AND TIN PLATE COMPANY, Pittsburgh, Pa. 